\title{
NEMATODE PARASITES OF BRAZILIAN PELECANIFORMES AND TROGONIFORMES BIRDS: A GENERAL SURVEY WITH NEW RECORDS FOR THE SPECIES
}

\author{
J. Júlio Vicente ${ }^{1,2}$ \\ R. Magalhães Pinto 1, 2 \\ Dely Noronha ${ }^{1}$ \\ Patrícia Goulart de Carvalho ${ }^{1,3}$
}

\begin{abstract}
This report deals with the identification of one hundred and seventy-one samples of nematodes recovered from Brazilian birds collected by Lauro Travassos and his staff, between 1921-1960. Aprocta travassossi Caballero, 1938, Aprocta sp., Baruscapillaria appendiculata (Freitas, 1933) Moravec, 1982, Contracaecum plagiaticium Lent \& Freitas, 1948, C. spiculigerum (Rudolphi, 1809) Railliet \& Henry, 1912, Contracaecum sp., Cyrnea (C.) semilunaris (Molin, 1860) Seurat, 1914, Oxyspirura sp., Paronchocerca ibanezi (Freitas, Vicente \& Pinto, 1970) Anderson \& Bain, 1976, Porrocaecum sp., Procyrnea sp., Skrjabinura spiralis Gnédina, 1933, Subulura acutissima Molin, 1860, S. bentocruzi Barreto, 1919, S. travassossi Barreto, 1919, Subulura sp. and Tetrameres sp. were studied. Contracaecum spiculigerum and Aprocta travassossi are redescribed and referred for the first time in South America. New host records were established for most of the species.

KEY WORDS. Nematodes, Pelecaniformes, Trogoniformes, birds, Brazil
\end{abstract}

The present investigation reports to helminthological findings related to avian hosts and was scheduled to add new data on morphometrics, of two species as well as new host records and geographical distribution of nematodes found parasitizing Brazilian birds. The results so far obtained further accomplish those previously reported (PINTO et al. 1991, 1993, 1994; PINTO \& VICENTE 1995; VICENTE et al. 1993, 1995 a,b) and deal with nematodes recovered from the brown booby, as well as from cormorants, anhingas and trogons in Brazil (Tab. I).

\section{MATERIAL AND METHODS}

One hundred and seventy-one samples recovered between 1921 and 1960 in Brazilian north, southeastern and mid-eastern regions and deposited in the Helminthological Collection of the Oswaldo Cruz Institute (CHIOC) were studied. Speci-

1) Laboratório de Helmintos Parasitos de Vertebrados, Departamento de Helmintologia, Instituto Oswaldo Cruz. Avenida Brasil 4365, 21045-900 Rio de Janeiro, Rio de Janeiro, Brasil.

2) CNPq research fellows.

3) PAP'S/IOC scholarship holder. 
mens are kept in numbered vials, matched with respective numbered files that contain data on the unidentified samples, regarding host, site of infection, locality of capture, preservative solution, date of necropsy and name of the collector.

The source of samples according to host order and family is: Pelecaniformes, Phalacrocoracidae: 39 from Phalacrocorax b. brasilianus (Gmelin, 1789); Anhingidae: 51 from Anhinga a. anhinga Linné, 1766; Fregatidae: 1 from Fregata sp.; Sulidae: 1 from Sula l. leucogaster (Boddaert, 1783); Trogoniformes, Trogonidae: 37 from Trogon curucui behni Gould, 1875; 19 from Trogon c. curucui Linné, 1766; 1 from Trogon s. surrucura Vieillot, 1817; 17 from Trogon v. viridis Linné,1766; 5 from Trogon sp.

Table I. Nematodes from Pelecaniformes and Troaoniformes birds in Brazil.

\begin{tabular}{|c|c|}
\hline Parasite species & Host species \\
\hline \multirow[t]{2}{*}{ Aprocta travassossi } & Trogon curucui behni Gould, 1875 (T) \\
\hline & Trogon curucui curucui Linnaeus, 1766 (T) \\
\hline Aprocta sp. & Trogon viridis viridis Linnaeus, $1766(\mathrm{~T})$ \\
\hline Baruscapillaria appendiculata (Freitas, 1953) Moravec, 1982 & Phalacrocorax brasilianus brasilianus (Gmelin, 1789) (P) \\
\hline Baruscapillaria spiculata (Freitas, 1953) Moravec, 1982 & Phalacrocorax brasilianus brasilianus $(\mathrm{P})$ \\
\hline Capillaria sp. & Anhinga anhinga anhinga Linnaeus, $1766(P)$ \\
\hline Contracaecum granulosum (Scheineider, 1866) Baylis, 1932 & Fregata magnificens Matheus, $1914(\mathrm{P})$ \\
\hline Contracaecum multipapillatum (Drasche, 1882) Baylis, 1932 & Anhinga anhinga Linnaeus, $1766(P)$ \\
\hline Contracaecum plagiaticium Lent \& Freitas, 1948 & Sula leucogaster leucogaster (Boddaert, 1783) (P) \\
\hline \multirow{2}{*}{$\begin{array}{l}\text { Contracaecum spiculigerum (Rudolphi, 1809) Railliet \& Henry, } \\
1912\end{array}$} & Phalacrocorax brasilianus brasilianus $(\mathrm{P})$ \\
\hline & Anhinga anhinga anhinga (P) \\
\hline \multirow[t]{3}{*}{ Contracaecum sp. } & Phalacrocorax brasilianus brasilianus (P) \\
\hline & Anhinga anhinga anhinga (P) \\
\hline & Fregata sp. (P) \\
\hline Cyrnea (Cyrnea) semilunaris (Molin, 1860) Seurat, 1914 & Trogon curucui curucui (T) \\
\hline \multirow[t]{2}{*}{ Eustrongylides sp. } & Phalacrocorax brasilianus brasilianus $(\mathrm{P})$ \\
\hline & Anhinga anhinga $(\mathrm{P})$ \\
\hline Onchocerca sp. & Anhinga anhinga $(\mathrm{P})$ \\
\hline Oxyspirura sp. & Trogon curucui curucui (T) \\
\hline $\begin{array}{l}\text { Paronchocerca ibanezi (Freitas, Vicente \& Pinto, 1970) Anderson } \\
\text { \& Bain, } 1976\end{array}$ & Anhinga anhinga $(\mathrm{P})$ \\
\hline Porrocaecum sp. & Phalacrocorax brasilianus brasilianus (P) \\
\hline \multirow[t]{4}{*}{ Procymea sp. } & Trogon sp. (T) \\
\hline & Trogon viridis viridis $(\mathrm{T})$ \\
\hline & Trogon curucui behni ( $\mathrm{T})$ \\
\hline & Trogon curucui curucui (T) \\
\hline Skrjabinura spiralis Gnedina, 1933 & Trogon curucui behni (T) \\
\hline \multirow[t]{3}{*}{ Subulura acutissima Molin, 1860} & Trogon viridis viridis $(\mathrm{T})$ \\
\hline & Trogon curucui curucui $(\mathrm{T})$ \\
\hline & Trogon curucui behni (T) \\
\hline \multirow[t]{2}{*}{ Subulura bentocruzi Barreto, 1919} & Trogon vinidis viridis $(\mathrm{T})$ \\
\hline & Trogon sp. \\
\hline Subulura travassossi Barreto, 1919 & Trogon viridis viridis $(\mathrm{T})$ \\
\hline \multirow[t]{4}{*}{ Subulura sp. } & Trogon sp. \\
\hline & Trogon vindis viridis $(\mathrm{T})$ \\
\hline & Trogon surrucura surrucura Vieillot, 1817 (T) \\
\hline & Trogon curucui curucui (T) \\
\hline Tetrameres sp. & Anhinga anhinga anhinga $(P)$ \\
\hline Thelazia dacelonis (Breinl, 1913) Travassos, 1918 & Trogon melanurus melanurus Swainson, $1838(\mathrm{~T})$ \\
\hline
\end{tabular}

*. (P) Pelecaniformes, (T) Trogoniformes.

Revta bras. Zool. 13 (4): 891 - 901, 1996 
Nematodes were preserved in Railliet \& Henry's solution $(0.85 \% \mathrm{NaCl}$ solution: $93 \mathrm{ml}$; formaldehyde: $5 \mathrm{ml}$; glacial acetic acid: $2 \mathrm{ml}$ ) and were processed for study as described elsewhere (VICENTE et al. 1993).

NHR and NGD indicate New Host Record and New Geographical Distribution, respectively. Classification and common names of hosts follow PINTO (1978), FRISCH (1981) and SICK (1984). Confirmation of the taxonomic status of the nematodes was based on ANDERSON \& BAIN (1976, 1982), CHABAUD (1975a,b 1978), HARTWICH (1974). Specific diagnosis was achieved by comparison of the morphometric data actually obtained with those referred in the original descriptions and/or redescriptions, as well as with deposited type specimens whenever available in the CHIOC.

Preparation of "en face" mounts was in accord to the method of ANDERSON (1958). Illustrations were performed with a drawing tube connected to an Olympus light microscope. Measurements are in micrometers unless otherwise indicated.

\section{RESULTS}

\section{Aproctoidea, Onchocercidae}

\section{Aprocta travassossi Caballero, 1938}

Figs 1-4

Redescription. Morphometrics based on seven adult specimens, three males and four females, recovered from Trogon curucui behni.

Males (Figs 3,4). Body 7.7-10.4mm long, 290-350 wide. Mouth with circular sclerotized lining, with one pair of papillae in the inner circle and two pairs in the outer. Esophagus 720-840 long. Nerve ring 120-180 from anterior extremity. Excretory pore not observed. Spicules stout, similar, 230-260 long. Gubernaculum absent. Five pairs of caudal papillae: one pair is pre-cloacal, one ad- and three pairs are post-cloacal. Cloacal aperture $90-100$ from posterior extremity.

Females (Figs 1,2). Body 20,0-23.8mm long, 510-610 wide. Mouth identical to that observed in males. Esophagus $0.91-1.25 \mathrm{~mm}$ long. Nerve ring $160-220$ from anterior extremity. Excretory pore not observed. Vulva 560-780 from anterior extremity. Ovijector $2.31-2.80 \mathrm{~mm}$ long. Eggs $36-46$ long by $14-25$ wide. Rectum 210-270 long.

Anus 75-120 from posterior extremity.

Hosts. Trogon curucui behni; common name: blue-crowned trogon ("surucuá-de-coroa-azul") (NHR), Trogon c. curucui; (same common names as those of the above referred host) (NHR).

Site of infection. Body cavity.

Locality. Salobra, State of Mato Grosso do Sul, Brazil (NGD)

Specimens studied: CHIOC no. 33,608 a-d, 33,609 a-c (whole mounts), $11,392,11,524,11,607,12,958$ (wet material).

Remarks. This species was proposed (CABALLERO 1938) from specimens parasitizing the orbital cavity of the Trogoniformes Curucujus massena (sic) from 
Vera Cruz, Mexico and has not been referred ever since. This is the first report of Aprocta travassossi in South America.

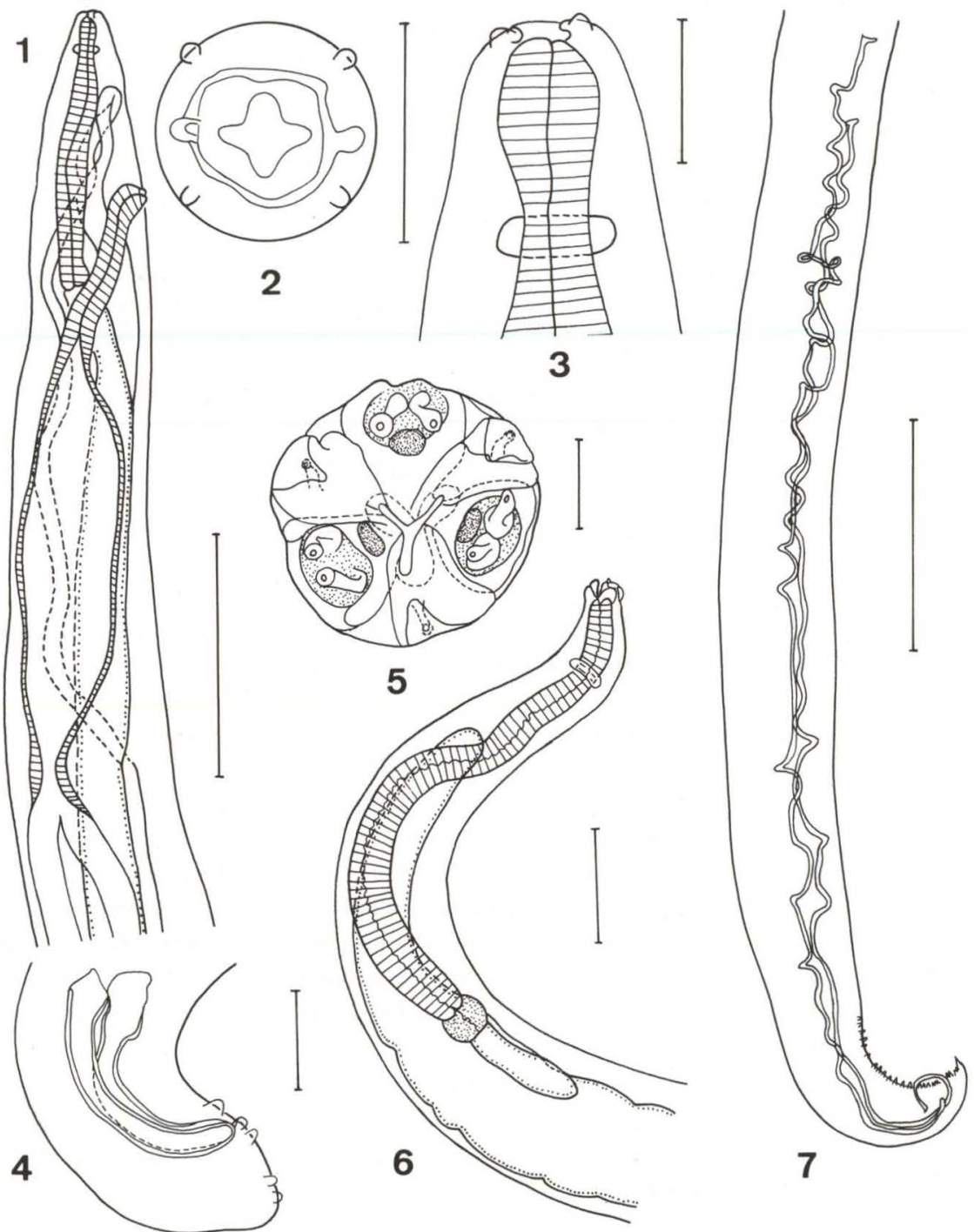

Figs 1-7. (1-4) Aprocta travassossi. (1) Anterior portion of female, lateral view; (2) head of female, "en face" view; (3) anterior extremity of male, lateral view; (4) posterior extremity of male, lateral view. (5-7) Contracaecum spiculigerum. (5) Head of female, "en face" view; (6) anterior portion of male, lateral view; (7) posterior portion of male, lateral view. Bars $=0.1 \mathrm{~mm}$ in figures $1-5 ; 0.5 \mathrm{~mm}$ in figure $6 ; 1.5 \mathrm{~mm}$ in figure 7 ). 


\section{Ascaridoidea, Anisakidae, Anisakinae}

\section{Contracaecum spiculigerum (Rudolphi, 1809) Railliet \& Henry, 1912}

Figs 5-7

Redescription. Morphometrics based on four adult specimens, two males and two females, recovered from Phalacrocorax $b$. brasilianus.

Males (Figs 6,7). Body 13.4-14.6mm long, 530-630 wide. Mouth with three prominent lips with a pair of papillae each and three interlabia presenting a papilla each. All papillae are pedunculate. Esophagus 1.96-2.24mm long. The ventriculus, esophageal appendix and the intestinal caecum are 110-150, 210-540 and 1.3$1.4 \mathrm{~mm}$ long, respectively. Nerve ring 350-370 from anterior extremity. Excretory pore not observed . Spicules slender, similar, 7.8-8.4mm long. Gubernaculum absent. There are about twenty pairs of pre-cloacal and five pairs of post-cloacal caudal papillae. Cloacal aperture 140-150 from posterior extremity.

Females (Fig. 5). Body 27.2-30.0mm long, 0.91-1.02mm wide. Mouth identical to that observed in males. Esophagus $2.6-2.8 \mathrm{~mm}$ long. The ventriculus, esophageal appendix and the intestinal caecum are $210-280,770-820$ and $1.96 \mathrm{~mm}$ long, respectively. Nerve ring 490-530 from anterior extremity. Excretory pore not observed. Vulva $7.31 \mathrm{~mm}$ from anterior end. Eggs 50 long by 40 wide. Anus 300-360 from posterior extremity.

Hosts. Phalacrocorax b. brasilianus; common name: neotropic cormorant ("biguá-miuá") (NHR); Anhinga a. anhinga; common name: anhinga ("biguá-tinga, anhinga").

Site of infection. Stomach.

Localities. Barranco Alto and Salobra, State of Mato Grosso do Sul; Porto Cabral, State of São Paulo; Rio de Janeiro, State of Rio de Janeiro, Brazil (NGD).

Specimens studied. CHIOC no. 33610 a-b, 33611 a-h, 33613 a-f (whole mounts); 2910-2913, 2943, 2945, 2951, 2993, 2994, 7029, 7055, 8103, 8117, 8118, $8147,8148,8151,8249,8334,8644,8664,8705,8710,8711,8713,8714,11373$, $11401,11779,12478,12539,12547,12548,12766,13054,13261,13262,13264$, $13266,14541,14702,14714,14717,14967,15040,15043,15052,15054,15055$, $15534,15,536,15544,15564,15567,15571,15587,26437$ (wet material).

Remarks. Contracaecum spiculigerum was the species of higher prevalence among the concerned hosts, representing $35.08 \%$ of the studied samples. Although referred in a wide range of Pelecaniformes from several localities (MosGovoY 1953), this is the first report of the species in South America, when a new host record for C. spiculigerum is also established.

Trichinelloidea, Trichuridae, Capillariinae

Baruscapillaria appendiculata (Freitas, 1933) Moravec, 1982

Host. Phalacrocorax b. brasilianus

Site of infection. Intestine. 
Locality. State of Mato Grosso do Sul, Brazil.

Specimens studied. CHIOC no. 8788 (wet material).

Remarks. Phalacrocorax b. brasilianus is the type host for this species, which was described from material obtained in Rio de Janeiro,State of Rio de Janeiro, Brazil (FREITAS 1933).

\section{Contracaecum plagiaticium Lent \& Freitas, 1948}

Host. Sula l. leucogaster; common name: brown booby ("atobá") (NHR)

Site of infection. Intestine.

Locality. Rio de Janeiro, State of Rio de Janeiro, Brazil.

Specimens studied. CHIOC no. 9530 (wet material).

Remarks. This species has been recently reported and figured in Brazil (VICENTE et al. 1995b) and no additional data on C. plagiaticium were obtained, except for its occurrence in a new host.

\section{Seuratoidea, Seuratidae, Seuratinae}

Skrjabinura spiralis Gnédina, 1933

Host. Trogon curucui behni (NHR).

Site of infection. Intestine.

Locality. Salobra, State of Mato Grosso do Sul, Brazil.

Specimens studied. CHIOC no. 13014 (wet material).

Remarks. Skrjabinura spiralis has been referred previously in Cuculiformes and Falconiformes hosts, according to PINTO et al. (1994).

\section{Subuluroidea, Subuluridae, Subulurinae}

\section{Subulura acutissima Molin, 1860}

Hosts. Trogon v. viridis; common name: black-throated trogon ("surucuáde-barriga amarela") (NHR), Trogon curucui behni (NHR), Trogon c. curucui (NHR).

Site of infection. Intestine.

Localities. Barranco Alto, Bodoquena and Salobra, State of Mato Grosso do Sul, Conceição da Barra and Linhares, State of Espírito Santo, Brazil

Specimens studied: CHIOC no. 11216, 11217, 11223, 11224, 11227, 11229, $11236,11312,11356,11391,11526,11542,11553,11564,11576,11577,11586$, $11608,11701,11783,12451,12460,12467,12509,12957,13015,13049,13288$, $13293,13294,13457,14533,14597,14858,14871,15108,15109,15112,15539$, 16955, 20456 (wet material).

Remarks. This species was represented in $24.5 \%$ of the studied samples. It has been referred in Brazil parasitizing other hosts than the Trogoniformes, namely the Cuculiformes and Strigiformes (VICENTE et al. 1995a). 


\section{Subulura bentocruzi Barreto, 1919}

Hosts. Trogon sp., Trogon v. viridis (NHR).

Site of infection. Intestine. Brazil.

Localities. Angra dos Reis, State of Rio de Janeiro, Cachimbo, State of Pará,

Specimens studied. CHIOC no. 5425, 5576, 21560(wet material).

Remarks. Subulura bentocruzi was previously referred in Trogon sp. and Trogon variegatus Spix, according to BARRETO (1919) and VICENTE et al. (1995a) and was found together $S$. acutissima in Trogon $v$. viridis.

\section{Subulura travassossi Barreto, 1919}

Host. Trogon v. viridis (NHR).

Site of infection. Intestine.

Localities. Angra dos Reis, State of Rio de Janeiro, Conceição da Barra, State of Espírito Santo, Brazil.

Specimens studied. CHIOC no. 6757, 14800, 14812, 14844 (wet material).

Remarks. Subulura travassossi was found together the two above referred species in the same host and parasitizes a wide range of birds, distributed in two orders: Caprimulgiformes and Piciformes (VICENTE et al. 1995a).

Habronematoidea, Habronematidae, Habronematinae

Cyrnea (Cyrnea) semilunaris (Molin, 1860) Seurat, 1914

Host. Trogon c. curucui.

Site of infection. Intestine.

Locality. Salobra, State of Mato Grosso do Sul, Brazil.

Specimens studies. CHIOC no. 11375 (wet material).

Remarks. There is no remarkable data to state further comments on this species, previously referred in the same host by PINTO \& GOMES (1985).

Filarioidea, Onchocercidae, Splendidofilariinae

Paronchocerca ibanezi (Freitas, Vicente \& Pinto, 1970)

Anderson \& Bain, 1976

Host. Anhinga a. anhinga (NHR).

Site of infection. Brain, stomach, intestine (sic).

Localities. Barranco Alto and Salobra, State of Mato Grosso do Sul, Brazil

Specimens studied. CHIOC no. 33612 (whole mount), 8501, 8682, 8685, $8686,8691,11417,14547,15540,15563,15665,15570$ (wet material).

Remarks. This species was proposed as Nicanoria ibanezi and included in the also proposed subfamily Nicanoriinae (FREITAS et al. 1970). Later, (ANDERSON 
\& BAIN 1976) synonymazed Nicanoriinae with Splendidofilariinae Chabaud \& Choquet, 1953 and Nicanoria Freitas, Vicente \& Pinto, 1970 with Paronchocerca Peters, 1936. Paronchocerca ibanezi only had been reported occurring in its type host, the Picidae Colaptes campestris (Vieillot, 1818), common named campo-flicker ("pica-pau-do-campo").

In some samples, the worms were in extremely fragile shape and most of the specimens were damaged. The outermost cuticle appears to have been stripped off or peeled away. In particular this stripping has affected the tail of the males, making the papillae appeared "naked", i.e not within caudal alae. In these cases one can suppose that this stripping or peeling is due to a harsh preservative (possibly acid-based) in which the specimens may have been stored at some time in the past.

For this reason, the following species are presented only in their generic status.

\section{Capillaria sp.}

Host. Anhinga a. anhinga.

Site of infection. Intestine.

Locality. Rio de Janeiro, State of Rio de Janeiro, Brazil.

Specimen studied. CHIOC no. 7033 (wet material).

\section{Contracaecum sp.}

Hosts. Phalacrocorax b. brasilianus, Anhinga a. anhinga, Fregata sp..

Localities. Barranco Alto and Salobra, State of Mato Grosso do Sul, Porto Esperança, State of São Paulo, Brazil.

Specimens studied. CHIOC no. 8109, 8227, 8637, 8643, 8654, 9536, 10454, $10458,12550,15576,15584$ (wet material).

\section{Ascaridoidea, Ascarididae, Toxocarinae}

\section{Porroacaecum sp.}

Host. Phalacrocorax b. brasilianus.

Site of infection. Stomach.

Locality. Barranco Alto, State of Mato Grosso do Sul, Brazil

Specimens studied: CHIOC no. 15566 (wet material).

\section{Subulura sp.}

Hosts. Trogon sp., Trogon v. viridis, Trogon s. surrucura; common name: surucua trogon ("surucuá-de-barriga vermelha"), Trogon c. curucui.

Site of infection. Intestine.

Localities. Cachimbo and Cachoeira do Tronco, State of Pará, Salobra, State of Mato Grosso do Sul, Ilha Seca, State of São Paulo, Brazil.

Specimens studied. CHIOC no. 9016, 9020, 11357, 11582, 11633, 12453, 21558 (wet material). 
Thelazioidea, Thelaziidae, Thelaziinae

\section{Oxyspirura sp.}

Host. Trogon c. curucui.

Site of infection. Eyes.

Locality. Salobra, State of Mato Grosso do Sul, Brazil.

Specimens studied. CHIOC no. 11374 (wet material).

Habronematoidea, Habronematidae, Habronematinae

\section{Procyrnea sp.}

Hosts. Trogon sp., Trogon v. viridis, Trogon curucui behni, Trogon c. curucui.

Site of infection. Gizzard.

Localities. Cachimbo and Cachoeira do Tronco, State of Pará, Engano, State of Espírito Santo, Bodoquena and Salobra, State of Mato Grosso do Sul, Brazil.

Specimens studied. CHIOC no. 9018, 11700, 12453, 12471, 12956, 13169, $14843,14869,16954,21559,21685$ (wet material).

\section{Habronematoidea, Tetrameridae, Tetramerinae}

\section{Tetrameres sp.}

Host. Anhinga a. anhinga

Site of infection. Gizzard.

Locality. Rio de Janeiro, State of Rio de Janeiro, Brazil.

Specimen studied. CHIOC no. 7027 (wet material).

\section{Aprocta sp.}

Host. Trogon v, viridis.

Site of infection. Body cavity.

Localities. Cachoeira do Tronco, State of Pará, Conceição da Barra, State of Espírito Santo, Salobra, State of Mato Grosso do Sul, Brazil.

Specimens studied. CHIOC no. 9021, 11218, 12452, 14798 (wet material).

Other nematode species referred parasitizing the hosts concerned herein and not found during the present investigation are: Capillaria spiculata Freitas, 1933 and Eustrongylides sp. in Phalacrocorax b. brasilianus; Contracaecum multipapillatum (Drashe, 1882) Baylis, 1920, Eustrongylides sp. and Onchocerca sp. in Anhinga anhinga, Contracaecum granulosum (Schneider,1866) Baylis, 1932 in Fregata magnificens Matheus, 1914 and Thelazia dacelonis (Breinl, 1913) Travassos, 1918 in Trogon m. melanurus Swainson, 1838, according to VICENTE et al. (1995a). 


\section{REFERENCES}

ANDERSON, R.C. 1958. Méthode pour lxamen des nématodes en vue apicale. Ann. Par. hum. comp. 33: 171-172.

ANDERSON, R.C. \& O. BAIN. 1976. Keys to the genera of the order Spirurida. Diplotriaenoidea, Aproctoidea and Filarioidea, p.59-116. In: R.C. ANDERSON, A.G. ChabAud \& S. WillmotT (Eds). CIH Keys to the nematode parasites of vertebrates 3. England, Commonwealth Agricultural Bureaux, Farnham Royal Bucks, part 3.

1982. Keys to the genera of the superfamilies Rhabditoidea, Dioctophymatoidea, Trichinelloidea and Muspiceoidea, p.1-26. In: A.C. ANDERSON, A.G. ChabAUD \& S. WillmotT (Eds). CIH Keys to the nematode parasites of vertebrates. England, Commonwealth Agricultural Bureaux, Farnham Royal Bucks, Part 9.

BARreto, A.L.B.B. 1919. Revisão da subfamília Subulurinae Travassos, 1914. Mem. Inst. Oswaldo Cruz 11: 1-70.

CABALLERO, E.C. 1938. Contribución al conocimiento de los nematodos de las aves de México. V. Liv. Jub. Prof. Lauro Travassos, p.91-97.

Chabaud, A.G. 1975a. Keys to the genera of the order Spirurida. Camallanoidea, Dracunculoidea, Gnathostomatoidea, Physalopteroidea, Rictularioidea and Thelazioidea, p.1-27. In: R.C. ANDERson, A.G. Chabaud \& S. WillmotT (Eds). CIH Keys to the nematode parasites of vertebrates 3. England, Commonwealth Agricultural Bureaux, Farnham Royal Bucks, part 1.

$1975 \mathrm{~b}$. Keys to the genera of the order Spirurida. Spiruroidea, Habronematoidea and Acuarioidea, p.29-58. In: R.C. ANDERSON, A.G. CHABAUD \& S. Willmott (Eds). CIH Keys to the nematode parasites of vertebrates 3. England, Commonwealth Agricultural Bureaux, Farnham Royal Bucks, part 2. . 1978. Keys to the genera of the superfamilies Cosmocercoidea, Heterakoidea and Subuluroidea, p.1-71. In: ANDERSON, Chabaud \& WiLlmotT (Eds). CIH Keys to the nematode parasites of vertebrates 6. England, Commonwealth Agricultural Bureaux, Farnham Royal Bucks.

FREITAS, J.F.T. 1933. Nouvelles espèces du genre Capillaria Zeder, 1808. C.r. Soc. Biol. Paris 114: 1195-1196.

Freitas, J.F.T.; J.J. VicEnTE \& R. MAgalhães Pinto. 1970. Sobre uma filária prodelfa parasita de ave (Nematoda, Filarioidea). Atas Soc. Biol. Rio de Janeiro 12 (supl.): 39-42.

FrISCH, J.D. 1981. Aves brasileiras 1. Dalgas-Ecoltec Ecologia Técnica, São Paulo, 353p.

HARTWICH, G. 1974. Keys to the genera of the Ascaridoidea, p.1-27. In: ANDERSON, Chabaud \& WillmotT (Eds). CIH Keys to the nematode parasites of vertebrates 2. England, Commonwealth Agricultural Bureaux, Farnham Royal Bucks.

Mosgovoy, A.A. 1953. Ascaridata dos animais e do homem e doenças causadas por eles. Pt. II, p.1-616. In: K.I. SKRJABIN (Ed.). Princípios de nematodologia. 2. Moscou, Akad. Nauk. SSSR. 
PINTO, O.M.O. 1978. Novo catálogo de aves do Brasil 1. São Paulo, Empresa Gráfica da Revista dos Tribunais, 446p.

PINTO, R.M. \& D.C. GOMES. 1985. Nematodes of Amazonian birds, with a description of Hoazinstrongylus amazonensis n.gen. n.sp.. (Trichostrongylidae, Libyostrongylinae). Mem. Inst. Oswaldo Cruz 80: 213-217.

PINTO, R.M. \& J.J. VICENTE. 1995. Tetrameres (Tetrameres) spirospiculum n. sp. (Nematoda, Tetrameridae) from the buff-necked ibis, Theristicus caudatus caudatus (Boddaert) (Aves, Threskiornitidae). Mem. Inst. Oswaldo Cruz 90: 615-617.

PINTO, R.M.; J.J. ViCENTE \& D. NoRONHA. 1993. Nematode parasites of Brazilian psittacid birds, with emphasis on the genus Pelecitus Railliet \& Henry, 1910. Mem. Inst. Oswaldo Cruz 88: 279-284.

1994. Nematode parasites of Brasilian acciptrid and falconid birds (Falconiformes). Mem. Inst. Oswaldo Cruz 89: 359-362.

PINTO, R.M.; J.J. VICENTE; D. NORONHA \& S.P. FÁBIO. 1991. New records for the nematodes Ascaridia columbae (Gmelin) Travassos, Acuaria mayori Lent, Freitas \& Proença and Aproctella stoddardi Cram in Brazilian birds, with redescription of the species. Revta bras. Zool. 8: 1-6.

SICK, H. 1984. Ornitologia brasileira, uma introdução. Brasília, Universidade de Brasília, 474p.

Vicente, J.J.; H.O. Rodrigues; D.C. Gomes \& R. Magalhães Pinto. 1995a. Nematóides do Brasil. Parte IV: Nematóides de aves. Revta bras. Zool. 12 (Supl. 1): 1-273.

Vicente, J.J.; R. Magalhães Pinto \& D. NoRonha. 1993. Remarks on six species of heterakid nematodes parasites of Brazilian tinamid birds with a description of a new species. Mem. Inst. Oswaldo Cruz 88: 271-278.

Vicente, J.J.; R. Magalhães Pinto; D. Noronha \& L. GonÇAlves. 1995b. Nematode parasites of Brazilian Ciconiiformes birds: a general survey with new records for the species. Mem. Inst. Oswaldo Cruz 90: 389-393.

Recebido em 24.XI.1995; aceito em 28.XII.1996. 